\title{
Natality. A theological approach to an anthropological basic concept in the context of bioethics ${ }^{1}$
}

U H J Körtner

(University of Vienna) $^{2}$

\section{ABSTRACT \\ Natality. A theological approach to an anthropological basic concept in the context of bioethics}

In the controversy about the introduction of new biotechnological and medical technologies, their judicial regulation and political control, not only so-called moral values are discussed but ultimately also religious credos. By the example of natality it will be shown what theology can contribute to the clarification of basic categories of anthropology, which are crucial for medical ethics. The term "natality" ("Geburtlichkeit") derives from the philosopher Hannah Arendt. In terms of the human finiteness, attention is usually turned to the mortality of the human being. Yet what does it mean for human existence that we are born? What role does this factor play with regard to concrete problems in medical ethics, and which perspectives can theology contribute in terms of their solution?

\section{MEDICAL ETHICS AS APPLIED ANTHROPOLOGY}

The most basic question regarding the subject matter of both ethics and medicine is: What is the human being? Modern reproductive endocrinology, in the field of stem cell research as well as ethical problems regarding the end of life - the debate concerning the criteria for brain death - raises a further question: When does human life start and when does it come to an end? Bio-political and medical ethical debates provide room for asking elementary questions about the meaning of life and death, illness and suffering, health and happiness, value and dignity, salvation and healing.

The Protestant theologian Wolfgang Trillhaas held the view that all ethics is "applied anthropology" (Trillhaas 1970:19). The

1 Guest lecture at University of Pretoria, presented on 1 August 2007, and at University of Stellenbosch, presented on 10 August 2007, translated by Tobias J Körtner.

2 Research associate of professor D E Villiers of the Department of Dogmatics and Christian Ethics, Faculty of Theology, University of Pretoria. 
term "applied anthropology" is certainly as problematic as the recent common term "applied ethics". It creates the impression that it is merely about applying in a casuistic way an already fixed idea of humankind to practical problems of life conduct. Who or what is applied here by whom to what? Who is the subject of the application? Who are the addressees? And does "applied anthropology" mean that anthropological reflection comes before action, or does it rather mean that anthropological reflection is subsequently used to render decisions to act accountable? Likewise, it is unclear what "applied ethics" aims to apply: principles, criteria and norms or models, paradigms, examples and experiences?

The tasks and subject of, for example, medical ethics are characterised more accurately by the term "field ethics" ("Bereichsethik"), introduced in the German discussion by Julian Nida-Rümelin, rather than by the term "applied ethics" (NidaRümelin 1996:63). This term presumes that we are confronted by different fields of practice with differing kinds of problems that demand different sorts of ethical reflection (Fischer 2002b: 34). The aim of ethical reflection is not simply to adapt morality and the ethos respectively to the alleged "inherent necessities" of the various fields of practice, neither does it attempt to "codify and fix" the moral status quo. Its essence is rather to control moral standards of the traditional ethos constantly in a discerning way and to examine its impacts on the social and individual practice (Honecker 1999:272).

The same applies to anthropology. What a human is, what he can be, should be or wants to be is not predetermined but needs to be reconsidered time and again in all ethical conflicts about medical and technical innovations, in political and social developments and changes. Ethics in general, medical ethics in particular, and practical instead of applied ethics would be more apt terminology.

Discussions concerning the controversy about the introduction of new biotechnological and medical technologies, legal regulation and political control, include not only so-called moral values but ultimately also religious beliefs. The technological progress creates open or latent religious hopes, therefore sensitivity and discretion are required. This is not exclusively the concern of philosophy or religious studies, but is also a field of theology.

Religious attitudes not only influence the cultural and political environment of medical research, but also have a practical impact on 
the health- and illness-behaviour of the individual. The different perceptions of illness and health, salvation and healing, of body, spirit and soul necessitate concepts of intercultural and multicultural medicine respectively. Medicine and care in a multicultural society not only imply respect for other cultures and religions, but also necessitate a high degree of hermeneutic competence. Intercultural medicine and care in a globalised world need to be religion-sensitive and simultaneously be convinced that there are moral convictions which go beyond the boundaries of cultures.

By means of a specific example I would like to illustrate what theology can contribute to the clarification of basic categories of anthropology which are crucial for medical ethics. Let us choose the example of natality. In terms of human finiteness, attention is usually turned to the mortality of the human being. Yet what does being born mean for human existence? What role does this factor play with regard to concrete problems in medical ethics, and which perspectives can theology contribute in terms of a solution?

The methodical approach, which I choose for these questions, is a phenomenological and a hermeneutic one respectively. I would like to clarify the interrelation between ethics and hermeneutics with reference to the phenomenon of the natality of man, and thus demonstrate what a hermeneutic theology can accomplish in the field of ethics.

\section{PHILOSOPHY AND THEOLOGY OF THE PERSON}

A constitutive anthropological stipulation, which is also to be found in ecclesiastic statements concerning socio- and bioethical issues, states that the human being is a person. The Evangelic church quotes in ecumenical harmony: "Man is person. That is the basis of all ethical propositions" ("... und der Fremdling, der in deinen Toren ist" 1997:Nr. 97). Viewed theologically, the acceptance of the human being as a person is, according to the churches, rooted in God's acceptance of the human being (Gott ist ein Freund des Lebens 1989:42). The dignity of the person or rather the dignity of the human being is linked with the biblical notion of a human being as the image of God. On closer examination, however, it becomes apparent that the theological term can also be interpreted in different ways. The differentiation between an ontological concept of person, which is said to belong to Catholic tradition, and a relational concept of person, which is said to be typically Protestant, only indicates the 
existing problems in a very rough outline. For the rest, neither the theological nor the philosophical concept of person is identical with the biblical notion of man as the image of God, but should rather be understood as its conceptual specification (Thönissen 2001:114). This way, theology and the church wish to establish the connection between Christian anthropology and secular discourses about human dignity and human rights, for example within medical ethics.

"The concept of the person", explains the philosopher Dieter Sturma, "is the modern answer to the ancient question of the human self-conception" (Sturma 2001:11). Since modern sociology pronounced the human being and the subject dead, philosophy of the person strives towards their rehabilitation. In the light of the boost ethics has received in recent years this is not surprising. Ethics fails to describe and explain itself and its subject without regard to the concept of the person.

But how does someone become a person? And how does he come into this world? One thesis, which shall be discussed here, says: a persons is born. This argument clearly limits the use of the concept of person. Mammals, including humans are born, yet birds or reptiles which hatch from eggs, are not, neither are most types of fish and other creatures that proliferate through cell division, like for instance amoebae or paramecia; nor plants, machines and computers, angels - and also not God.

In Christian tradition the concept that the divine logos was the son, born of the father in eternity - born, not generated - does not harm this statement. God, in his Trinity, in his unity and in his very self, is unborn. The eternal natality of logos, like the personality of Father, Son and Holy Spirit, can at best be expressed and imagined in a figurative, not a literal way.

In the Bible, humans are primarily called "person". In the Old Testament, for instance, it is said several times that God regards all people equal. Accordingly, judgement in court should also be impartial $^{3}$. In these passages, Hebrew panä or panim is translated

3 For instance Dt 1:17; 10:17; Job 32:21; 34:19; Pr 24:23; 28:21. 
with "person" which firstly denotes the human countenance. The Greek p r 0 s wp on corresponds with that in the New Testament $\tilde{t}^{4}$.

Metaphorically speaking, the Old and New Testament can also denote the countenance of $\mathrm{God}^{5}$. The eschatological hope of faith consists in the ability to see God "face-to-face" (1 Cor 13:12) some day. Admittedly, one has to be aware of the metaphorical character of such phrasings. If one would award God the status of being a person in the literal sense (e.g. Herms 2003:1126), God no longer would be the Very Other and the origin of all things, but would belong to the class of persons, next to humans.

If persons are born, and being born is a feature of persons, this certainly does not mean that all creatures that are born are therefore persons. With the exception of the human being, the status of being a person is usually not attributed to all mammals. In the case of apes, this is nowadays as disputed as the assumption that all humans are persons. Whether anencephalic patients, vegetative patients or people suffering from Alzheimer in an advanced state can still be considered as persons, is a matter of conflict, just like the status of person of newborns. The thesis proposing that persons are born does not provide any information on this. Neither does it claim that birth is a sufficient criterion, nor that it is a necessary criterion for being a person. In this case, the unborn would have to be denied the status of person categorically. Does birth constitute or merely characterise a person? Is birth the temporal beginning of existence and history or just a moment of incision in its course? We have to go further into this question in order to clarify what constitutes the necessary and sufficient criteria for being a person.

"Human" and "person" are descriptive as well as normative terms. Following Peter F Strawson, I act on the assumption that it is furthermore a matter of coextensive terms, which explain each other reciprocally. Strawson has demonstrated that "person" has to be understood in terms of character, to which so-called "Person-

42 Cor 1:1; Col 2:1; Jude 1:16. See also the verb pros wpol hpt ew and derivates in Ac 10:34: oLk ekt in proswpol hpt h ol qeor (cf. Dt 10:17; Sir 35:12f); Ja 2:1.9; 1 Pt 1:17.

5 In the OT: Ex 33:14; Dt 4:7; 2 Sm 21:1; Is 63:9; Ps 80:17; Lm 4:16 - in the NT: Mt 18:10; Ac 8:20; 1 Cor 13:12; 2 Th 1:9; Heb 9:24; 1 Pt 3:12; Rv $22: 4$. 
predicates" (like states of mind, actions, intentions, feelings, thoughts, memories) and also "Human-predicates" (like physical, i.e. spatiotemporal attributes and relations) are applicable (Strawson 1995:111-149). The concept of person is, according to this reading, "logically primitive". It is not about combining some of the more primordial notions like "consciousness" or "body", but both types of predicates can be invariably applied to one and the same referential object. Consequently persons are creatures which we view as actual or possible subjects of consciousness and as objects of reciprocal attribute and interpretation. Yet this means that the terms "human" and "person" not only refer to the same entities, but also interpret each other (Wildfeuer 2000:9).

\section{NATALITY AND HISTORICITY}

If persons are born, and being born therefore is characteristic of persons, this of course does not mean that all creatures that are born are therefore persons. Indeed, not only humans but all mammals are born. Still, the human being can and has to respond to the fact of being born. Strictly speaking, only the human being is born. "Animals whelp, spawn or prick", as the theologian Hermann Timm remarks in a lapidary style (Timm 1996:47) ${ }^{6}$. Hannah Arendt has coined the term of natalilty for the phenomenon that a human's entire life is determined through his state of being born (Arendt 2001:17f.215ff) ${ }^{7}$. Hans Saner speaks of "Geburtlichkeit" (Saner $1995: 30)^{8}$. Whereas birth is the unique event of our entry into the world of things and people, natality, according to Arendt and Saner, refers to a feature of the born subject. Not mortality alone, but also natality defines the finiteness of man.

Natality implies origin, sexuality and sociality. Man is zon pol it ikom, because man is conceived and born, but after his birth he is dependent on extreme care and on education and learning, in order to become what he is. As a born creature a human has a history that can be recounted. His historicity, which characterises his form of existence, consists in "being involved in stories", as has been demonstrated by the follower of Husserl, Wilhelm Schapp (Schapp

6 Timm relies on Saner (1995:16).

7 The original version was publish under the titel "The Human Condition" (Arendt 1958). Quotations in this paper rely on the German translation.

8 Saner refers explicitly to H Arendt. See also Timm (1996:51ff). 
1985; Schapp 1981). This is exactly what distinguishes man's existence from things. Being involved in stories means to be aware of successive generations. "Hence, the Eros-driven logos is", as Volker Gerhardt states, "not just only dependent on production but on generation" (Gerhardt 2001:54). Gerhardt adds the assumption: "Maybe reason with its intermediatory services only exists because individuals have to indicate themselves to their peers, even beyond their lifetimes?" (Gerhardt 2001:54) Hence, natality and origin do not only mark man and his body as nature, but also his rationality, which is regarded in the tradition as a crucial criterion of being a person.

Three decades ago, the theologian and medical ethicist Dietrich Ritschl already developed his story-concept, which links up with the significance of story-telling for the biblical tradition as well as psychoanalysis (Ritschl 2004:53ff.131ff.) ${ }^{9}$. His medical-ethical concept can thus be connected with conceptions of narrative theology. For Ritschl, the story-concept generally functions as an ethical framework, specifically for medical ethics ${ }^{10}$. Ethical decisions at the bedside call for an intensive preoccupation with the patient's biography. This includes on the one hand the patient's previous life story in the form of his "stylised past" (Ritschl 2004:138), yet on the other hand also the "anticipated life story" (Ritschl 2004:133). Without such an anticipation, which ultimately places the human being for Ritschl in the eschatological horizon of God's "total story" (Ritschl 2004:139), the use of medical activities and forbearances cannot be evaluated.

\section{TRANSCENDENCE OF NATALITY?}

An existential interpretation of our natality alone does of course not determine whether natality is a sufficient or at least a necessary criterion for being a person. Because in this case the unborn would have to be denied its status of person categorically. Is a person constituted by birth or merely characterised? Is birth the temporal starting point of his existence and story, or just a dramatic event in its course?

$9 \quad$ See also Ritschl \& Jones (1976); Ritschl (1984).

10 The connection between illness and biography or between illness and story is also an issue in medical- sociological and medical-ethical literature. $\mathrm{Cf}$. Morris (2000:231ff); Akashe-Böhme \& Böhme (2005:23ff). 
According to the philosopher Volker Gerhardt, birth marks not only a caesura in human life that distinguishes between 'before' and 'after', but for him it is the actual "act of incarnation" in the first place (Gerhardt 2001:41). As Gerhardt admits, birth does indeed not "appear from nowhere", but that which was before birth is like that which comes after death, "qualitatively different from the individually experiencing personal life of man" (Gerhardt 2001:42). The qualitatively new life, beginning with birth, is the adjustment to an autonomous metabolism. The newborn has to change over to its own ingestion. "It breathes on its own for the first time. And so it can also make its voice, the 'organ of reason', resound for the first time" (Gerhardt 2001:46).

Hannah Arendt sees a repetition and confirmation of the divine act of creation in birth - not in procreation. Contrary to creatio ex nihilo, "not nothing but nobody" exists before birth (Arendt 2001:216). According to Arendt, this is not only true for the the human race as it appears in evolutionary history, but also for every single individual. Therefore, it is only possible to say of every new human that there was 'nobody' before his birth in reference to himself” (Arendt 2001:217).

According to Arendt's view, the justification of personhood in birth is transcendental. Arendt speaks of the beginning of man and which comes into being with his birth. "Together with the creation of man, the principle of beginning, which during the Creation of the world still remained in God's hands and thus outside of the world, emerged in the world itself and it will remain inherent in it as long as humans exist" (Arendt 2001:216).

Like Arendt and Gerhardt, the theologian Johannes Fischer sees a qualitative leap in birth. This view matches the common understanding of the concept of person: "The name, by which a person is identified, is only adjudicated after birth. It follows that the concept of person marks a difference between unborn and born life" (Fischer 2002d:135) ${ }^{11}$. Fischer wants to justify this difference by means of the distinction between "existing in the sense of entirely developed" and "evolving humans" (Fischer 2002c:117). Not in principle but "doubtless", only born humans could present

11 Also V Gerhardt asks: "Why is the name given after birth and not at the moment of nidation?" (2001:42). 
themselves as persons to us and communicate with us (Fischer 2002c:113). Fischer moreover distinguishes between organism and the human being represented by this organism. An embryo or a foetus is therefore, in Fischer's opinion, not yet a human being, nor a growing human being, but the life of a growing human being (Fischer 2002c:112f) ${ }^{12}$. What is more, Fischer argues that not all embryos have the status of growing human beings, "but that this depends on the circumstances and developmental possibilities" (Fischer 2002c:117). For Fischer it follows that there is a twofold status of human life "by nature" (Fischer 2002c: 117), namely a life in which the evolution of a human being takes place, and a life in which that is not the case. Fischer concretely thinks of embryos not yet nidated and sentenced to die.

I agree with Fischer that totipotency is not a sufficient condition for assigning human existence and the status of person to a fertilised ovum or an embryo in an early stage. In the outline of the final passage of this article I shall illuminate my own views on the indeterminateness of the beginning of life which are in agreement with Fischer's views on some central issues, however, but differ from them on other matters. This is especially the case when Fischer explains that "evolving" lies between non-existence and existence (Fischer 2002c:115), and when he defines "existing" as "being entirely developed" (Fischer 2002c:117). Are we not bound to say that personhood is always evolving? What is meant by saying a human being is "entirely developed"? With reference to Fischer's argumentation concerning the moral status of embryos, apparently the viability after birth is meant. In ethical contexts, this is an important criterion, for instance in matters of life-support measures or therapy-abruptions in neo-natology. Yet, with regard to ontology and anthropology, one has to ask when is a human ever entirely developed, and whether this development persists as long as he is alive and his story lasts. Seen ontologically, the equation of viability with existence is also an insufficient definition of the term "existence".

Hans Saner is more accurate in this respect. He interprets the pre-natal being as "being-to-subsistence" (Saner 1995:23), in which case subsistence means "Being-in the world" in terms of Heidegger.

12 The term "life" that Fischer uses, is not precisely defined by him. 
The unborn human already exists in the world, and also his existence is already "a form of being an individual" (Saner 1995:22). Therefore, man is not only a growing human life, but a living being. For example, he can die without the mother dying or losing a part of her body; On the contrary, the foetus is able to survive the death of the mother and can be saved by a caesarean section. Yet its being is not being-in-the-world in the full sense of the word, because the foetus has an environment in the uterus too. That is why Saner advocates calling the unborn "fruit of womb" or "foetus" and not already "child" (Saner 1995:67).

One can argue phenomenologically that personhood means being-in-the-world ("In-der-Welt-sein") and that we mean birth when we say in German "auf die Welt kommen" which could be paraphrased as "coming into the world". Gerhard remarks in a lapidary way: "I have encountered nobody, who celebrates the day of his conception" (Gerhardt 2001:41). This phenomenological argument is no longer as strong as Gerhardt believes. Together with the advanced knowledge of conception and pregnancy - not least because of the widespread use of prenatal diagnostics and therapy to the point of prenatal surgical interventions - also the attitude of pregnant women and nascent parents towards the unborn has changed (Duden, Schlumbohm \& Veit 2002). Birth itself has largely lost its naturalness; the caesarean section as the procedure of choice is on the advance.

Parents often already know the gender of their child at an early stage of pregnancy. And often expectant mothers or parents already name their child, even if this name is of course still judicially invalid. Since the mortality-rate of newborns and even of premature infants has fortunately dropped dramatically thanks to medical developments, expectant parents behave as if their child was already born. A new practice is the so called baby-party, which is not celebrated after birth but already during pregnancy, with suitable presents for the child. Last but not least, new forms of building up a relationship with the unborn life also develop among couples who become pregnant via in-vitro fertilisation and grow into parenthood between hope and fear, failed attempts and eventually a successfully induced pregnancy. And finally, the change of attitude in dealing with miscarriages should be mentioned. Whereas in the past these were simply thrown into the hospital-waste, there are recently 
several burial grounds for miscarried fetuses to be buried and receive their own church services.

Being a person means that humans are each other's counterpart. Reciprocal communication can only happen this way. As long as a human is not yet born, he lacks that human counterpart. For its mother, in whose body it grows, and even more so for all other humans the unborn child is not entirely an autonomous counterpart. The newborn only becomes a counterpart after the complete birth process like those who are already born, who can distinguish each other as subjects. Only now they can be persons for each other, whereas the unborn child can only be a person in a unilateral way for its mother or other humans. Only when the child and other human beings can be a person for each other, the child can be a person for itself.

Developmental psychology teaches us that the infant still imagines itself to be in a symbiosis with its mother some time after birth and only gradually understands that it is an independent individual apart from the mother. Yet birth is the necessary condition for the formation of a subjective consciousness, which is able to distinguish between itself, its mother and other humans. Within the uterus the development of such an awareness would never be possible. In this respect, a qualitative leap to being-in-the-world occurs during birth.

However, can one legitimately connect birth with "beingperson" in a transcendental sense - thereby eluding all causal or scientific descriptions - so that one has to agree with Hannah Arendt that man before his birth is not a somebody but a nobody?

If being a person and personhood would be linked with the precondition of birth, personhood and human dignity would be dependent on arbitrary decisions and conclusions of those who decide on the life and death of unborn children. If being alive and being human depend on the decision of its members, not even birth is a sufficient condition for personhood and being a person. Since personhood cannot be abstractly distinguished as the nature of being a person, "birth" is also no biological brutum factum that is detached from man's cultural existence, but rather a sign, which always gains its meaning only in different cultural practices of interpretation.

According to Christian understanding, pregnancy and birth acknowledge the being of a person and personhood, which is not due 
to the will of other humans, but which is transcendental. A human being is not awarded the status of person, but being a person is acknowledged as a given fact ${ }^{13}$. That the legal capacity of natural persons begins at birth, must not be misinterpreted as an ontological statement about the nature of man. Law and ontology and law and morality respectively need to be distinguished. With regard to transcendence of the person, one has to differentiate between beginning and origin. The very beginning Arendt and Saner talk about, namely man's consistent ability to begin something new, presupposes his being born. Yet it emanates from an origin that ought not to be identified with birth, but which is rather only emblematically represented by it.

The thesis whereby natality is an identification of the nature of personhood has to be modified in such a way that the person does not only exist since birth, but evolves during pregnancy towards its birth. Not only would personal communication be impossible in the uterus, but during life in general. That distinguishes, for example, the life of a born human on a heart-lung machine from an unborn human, who is provided for through the mother's umbilical cord. Every human being, and that means every person, is destined for birth, even if this disposition may not be fulfilled in individual cases because of a miscarriage. Yet on this note, we can say of the born as well as the unborn human being that its existence is existentially affected by birth, which indicates its natality ("Geburtlichkeit") in a phenomenological way.

\section{BEING BORN AND CONCEIVED}

In this context, a theological issue in the narrower sense has to be pointed out. That the day of conception has not played a culturalhistorical role so far, as Gerhardt insinuates, does not hold true for biblical tradition. If one draws the comparison between the natality of man and the Christology of incarnation, one has to remember the quotation from Psalm 2:7 in Acts 13:33, Hebrews 1:5 and 5:5. These passages transfer the Old Testament Psalm: "Thou art my son; this

13 That is why the complete abrogation of legal regulations for the protection of the unborn in the context of abortion and their compensation by new paragraphs for the protection of pregnant women, which Saner (1995:75) suggests, are from an ethical viewpoint as well as from a juridical viewpoint not sufficient. 
day have I begotten thee" to Christ. This verse is a liturgical formula from one of the psalms of the kings, which interprets the new regent's enthronement as a divine conception. In Acts 13:33 the psalm aims interestingly at the resurrection of Jesus from the dead. Both passages in the Epistle to the Hebrews are also not about the bodily conception of Jesus, but they offer a metaphorical description of him as the Son of God and the power and dignity that is connected with it.

It certainly needs to be pointed out that the Hebrew jld in Psalm 2:7 can be translated either as "to conceive" or as "give birth to". Neutrally its meaning may convey "to originate". Even the Greek genna w, which is used by the Septuagint in this passage, has these various meanings. It is more often used for the father and means the act of "fathering", less for the mother in which case it means "to bear a child". "To originate" is yet another possible translation. Philologically, Psalm 2:7 can be translated as follows: "Thou art my beloved son, this day have I given birth to thee"14. Conception and birth, however, coincide with each other in the act of the king's enthronement, if one agrees with the translation "to beget".

Early-church dogma formation and its proposition of the conception of the Son of God, contributed towards a theology of the Trinity to ascertain the person of the Son as He differs from the Father. According to the statement of the NicaenoConstantinopolitanum, the Son is not just born by the Father (gennhqent a, Lat. Natum), but also begotten by him (monogenh $\forall$, Lat. unigenitum). The inspiration here is not primarily Psalm 2:7 but Johannine theology, which refers to the embodied logos as monogenh $\forall$ para; patro (Jn 1:14) and as monogenh $\forall$ qeo $\forall$ (Jn 1:18). ${ }^{15}$ The Greek monogenh $\forall$ means "unique in its geno " or "uniform in its kind", "singly created", yet also "only begotten" or "firstborn" . On a purely linguistic level, the same ambiguity of Psalm 2:7 is on hand. John 1:14 and John 1:18 usually translate M onogenh $\forall$ as "only begotten". Both verses of St John's prologue emphasise Christ's singularity and his exclusive belonging to God,

14 Cf. Grohmann (2006:75f).

15 See also Jn 3:16.18 and further references.

16 For antique references see Bultmann (1978:47f, Fn. 2). 
without any description of a mythical act of conception, which would be decidedly separated from the process of birth.

The molecular biologist Jens Reich loosely bases his opinion that without conception, human clones are denied the status of being human on the Christological ascertainment of the NicaneoConstantinopolitanum. . Should it ever happen that the method of reproductive cloning via cell nuclear transfer is applied to humans, the clone would -according to him - not be a member of humankind but a homunculus, a golem or a zombie. General acceptance of Reich's view would have serious consequences for the legal status of clones, since they could then not be awarded human rights in the strict sense of the word, at best analoguous rights. By means of such argumentation it would be possible to elegantly argue for cloning for the purpose of scientific or therapeutic use (which Reich, however, rejects - not categorically but for practical reasons). Yet I do not believe the reasons named by Reich to be sufficient, even though I agree with him and many ethicists that the totipotency of cells capable of developing do not constitute a sufficient criterion for man's existence and thus for human dignity.

Reproductive cloning is an assault on human dignity, because it violates every human's fundamental right to a twofold biological parentage. This right is implied in the basic determination that a human being is born (Körtner 2003). Furthermore, in the act of his conception via cell nuclear transfer, the new human is deprived of a right that all other humans have, namely the right of a new genome compared to his parents. That is what distinguishes the clone from an enzygotic twin. The latter shares the same genome with its twinsibling. Both, however, own a genome that is different from the one of their mutual parents. The recombination of genes in the process of fertilisation is not only absolutely useful for the gene pool of humankind, but also potentially useful for the individual, even if the possibility of gene- and chromosome-defects (mutations) cannot be ruled out. Since no recombination of genetic material takes place in cloning, it can be argued that this violates a fundamental right of the new human. It violates man's physical intactness, his right to life and his human dignity. Additionally to that, it also needs to be considered that the clone is entitled to the basic right of reproduction, which proponents of cloning claim for themselves in terms of a libertarian "reproductive autonomy". Yet the clone's fertility may be impaired. Impairments of the clone's genome - after 
all it stems from an adult somatic cell of which the genetic quality has a tendency to be inferior to that of germ cells - are passed on to the next generation.

It also needs to be taken into consideration that a distinction between biological and social parenthood has always been possible. Modern reproductive endocrinology also adds the fact that the woman whose ovum is used does not have to be identical with the woman who bears the child. This means that in the case of surrogacy, a child can have up to five parents. Additionally, if a human being is cloned, successive generations are skipped. If one ignores the genetic material inside the body of the mother's ovum, the clone's biological parents are his paternal or maternal grandparents. Biologically speaking, the "father" or "mother" of a clone is his brother or sister.

Nonetheless, it can be argued that even in the case of cloning via cell nuclear transfer, the basic fact of begetting human life is not abolished. So far, any attempt at reproductive cloning has to be seriously rejected as a violation of human dignity, yet this violation of human dignity, inherent in the clone's body, would not give us the right to deny him his personhood.

\section{BEING ALL EARS}

With regards to the continuity and discontinuity of person-like life before and after birth, the significance of the sense of hearing for the coherence of reason, language and personality also has to be taken into consideration. As is generally known, the German word "Vernunft" (reason) derives etymologically from "vernehmen" (to hear), which not only refers to cognitive comprehension, but also to sensory perception. The organ of perceptive reason is the human sense of hearing. Even before a human can speak, it is capable of language and exists linguistically, because it can hear. The receptivity of hearing and sense of hearing precede the activity of speaking. The person's ability to speak, which is considered to be a feature of personality and rationality, only develops via hearing. This is clearly evident in the case of congenital deafness, where substitute-languages are used for languages that should be communicated acoustically.

The word "persona" thus has to be read in two directions. The mask of a person, the face, is not only the medium by which a voice and therefore reason reach to the outside, but also the membrane 
through which voice and human language reach the inside. In the case of people with severe mental disabilities, the sense of hearing is also an organ of their personhood. The human being is not just a creature with a language - that is, a person - if and as long as it can speak, but already since it can hear. When a human being dies, the sense of hearing fades last of all.

Yet the sense of hearing does not only develop after birth but already during pregnancy. For a long time it has been believed that children are deaf not only before birth but even during the first days of their life. Modern embryology and developmental psychology show us that prenatal existence does not develop within a hermetic seclusion and stillness. The unborn child rather hears numerous noises inside the womb, not only the noises of the maternal body, for instance of the gastrointestinal tract, but also the mother's voice and sounds that intrude the mother's belly and amniotic sac from outside. Studies indicate that the foetus reacts on acoustic stimuli approximately from the $28^{\text {th }}$ week of pregnancy, that means more than two months before birth (Wilkening \& Krist 2002:398ff). Already four days after birth, infants are able to distinguish their mother's voice from other voices ${ }^{17}$. Experiments demonstrate that this can be traced back to the fact that the newborn has already heard its mother's voice during pregnancy. "Already before birth, children seem to be sensitive not only to the sound of human voices, but also, irrespective of specific voices, to acoustic patterns of language" (Wilkening \& Krist 2002:398). In this respect, the first cry after birth is a first response to the human voice, which the unborn child has already heard before birth.

The primacy of hearing over speaking has eminent theological relevance. With a critical side glance at Rudolf Bultmann's conception of believing and understanding, the underlying model of the decision provoked by the Kerygma, the concept of the hermeneutic circle and its category of pre-understanding, the New Testament scholar Hans Weder from Zurich has defined the ability to hear as a basic condition of believing (Weder 1986:145ff). Weder relies on Paul for this modified approach to a hermeneutic theology. Paul explains in Romans 10:17: "So then faith cometh by hearing

17 This is not the case in the case of the father's voice in comparison to the voices of strange men! 
[that means the sermon], and hearing by the word of God". Hearing is, according to Weder, the anthropological correlative to the Paulinian or reformist teaching of justification, because man as a hearing being is receptive. The advice, the promissio of divine mercy, the promise of forgiveness of sins, reaches him through hearing.

The sense of hearing is therefore the anthropological link for the biblical religion of the word: the believing human being is all ears. In this respect one can modify Luther's clause, according to which faith constitutes the person ${ }^{18}$, to the effect that hearing constitutes the person - namely the hearing of God's address, who calls us by our names. Without intending to downplay the caesura that birth means in the story of a human life, it is decisively relativised by the phenomenological and theological understanding of the significance of the sense of hearing for the existence of a person. Therefore, Arendt's thesis that there is "nobody" (Arendt 2001:217) before a human's birth in relation to himself also needs to be contradicted.

\section{THE INDEFINITENESS OF THE BEGINNING}

The beginning of an individual human life is subject to a general and not only a temporal indefiniteness. It can neither be equated with birth nor with the moment of conception. Theologically speaking, the secret of the human personality manifests itself in the indefiniteness of the beginning of life, which cannot be observed nor come into being by itself (Körtner 2005:104ff.; Körtner 2004:103ff.). Its transcendent origin does not coincide with a temporal beginning.

Biblically speaking, the origin of each human lies in God and his benevolent grace. The words of Psalm 139:16 has to be understood in this regard: "Thine eyes did see my substance, yet being unperfect; and in thy book all my members were written, which in continuance were fashioned, when as yet there was none of them". However, this transcendent origin must not be confused or equated with the temporal beginning of a biological process - the conception or fusion of the ovum and sperm cell inside the test-tube of the reproductive endocrinologist. It also needs to be taken into account that the psalmist makes a retrospective statement about his 
mysterious origin, which is not a scientific hypothesis but a laudation, a praise. And even seen from a purely embryological angle, one has to say that every unborn human being was a zygote at first, but that not every fertilised ovum develops into a human being. That the zygote does not develop into a human, but as a human, is therefore a mere statement with questionable consequences.

According to biblical understanding, physicalness, indeed, constitutively belongs to personhood and man's physical existence is a storied one, that is, a process including the body, its development and its alterations. Human personality, however, cannot be grasped by means of scientific-causal thinking, but rather remains transcendental in relation to this level of interpreting the world and dealing with it. Its natality neither coincides with conception nor with birth, since man, according to the New Testament's testimony, only attains his destiny when he is newly born out of the divine spirit (Jn 3:5-8) ${ }^{19}$.

\section{Consulted literature}

Akashe-Böhme F \& Böhme, G 2005. Mit Krankheit leben. Von der Kunst, mit Schmerz und Leid umzugehen. München: C H Beck.

Arendt, H 1958. The Human Condition, Chicago: University of Chicago Press

Arendt, H 2001. Vita activa oder Vom tätigen Leben. 12. Aufl. München: Pieper.

Bayertz, K 1991. Praktische Philosophie als angewandte Ethik, in Bayertz, K (Hrsg.), Praktische Philosophie. Grundorientierungen angewandter Ethik. Reinbek: Rowohlt 7-47.

Bultmann, R 1978. Das Evangelium des Johannes. 10. Aufl. Göttingen: Vandenhoeck \& Ruprecht (KEK II).

Duden, B, Schlumbohm, J \& Veit, P (Hrsg) 2002. Geschichte des Ungeborenen. Zur Erfahrungs- und Wissenschaftsgeschichte der Schwangerschaft, 17.-20. Jahrhundert, Göttingen: Vandenhoeck \& Ruprecht.

Fischer, J 2002a. Medizin- und bioethische Perspektiven. Beiträge zur Urteilsbildung im Bereich von Medizin und Biologie, Zürich: TVZ.

-, 2002b. Gegenseitigkeit - die Arzt-Patienten-Beziehung in ihrer Bedeutung für die medizinische Ethik, in Fischer, J 2002a, 15-34.

-, 2002c. Forschung mit embryonalen Stammzellen: Was ist konsensfähig, wo bleibt Dissens?, in: Fischer, J 2002a, 111-122.

19 Concerning the echatological destination of the believer's existence being born from God see also 1 Jn 2:29; 3:9; 4:7; 5:1.4.18, but also Ja 1:18; 1 Pt 1:3.23. 
-, 2002d. Aktive und passive Sterbehilfe, in: Fischer, J 2002a,123-151.

Gerhardt, V 2001. Der Mensch wird geboren. Kleine Apologie der Humanität. München: C H Beck.

Gott ist ein Freund des Lebens. Herauforderungen und Aufgaben beim Schutz des Lebens 1989. Gemeinsame Erklärung des Rates der EKD und der Deutschen Bischofskonferenz. Trier.

Grohmann, M 2006. Fruchtbarkeit und Geburt in den Psalmen, Habil. masch. Wien.

Herms, E 2003. s v Person IV. Dogmatisch. RGG, 4. Aufl. Bd. VI. Tübingen: Mohr Siebeck, 1123-1128.

Honecker, M 1999. Von der Dreiständelehre zur Bereichsethik. Zu den Grundlagen der Sozialethik. ZEE 43, 262-276.

Körtner, U 2003. Angriff auf die Menschenwürde. Ethische und theologische Argumente gegen das Klonen von Menschen. Amt und Gemeinde 54, 79-81.

-, 2004. Unverfügbarkeit des Lebens? Grundfragen der Bioethik und der medizinischen Ethik, 2. Aufl. Neukirchen-Vluyn: Neukirchener Verlag.

-, 2005. "Lasset uns Menschen machen". Christliche Anthropologie im biotechnologischen Zeitalter. München: C H Beck.

Morris, D B 2000. Krankheit und Kultur. Plädoyer für ein neues Körperverständnis. München: Kunstmann.

Nida-Rümelin, J 1996. Theoretische und angewandte Ethik: Paradigmen, Begründungen, Bereiche, in Nida-Rümelin, J (Hrsg), Angewandte Ethik. Die Bereichsethiken und ihre theoretische Fundierung, Stuttgart: Kröner, 2-85.

Ritschl, D \& Jones, H O 1976. "Story" als Rohmaterial der Theologie. München: Kaiser.

Ritschl, D 1984. Zur Logik der Theologie. München: Kaiser.

-, 2004. Zur Theorie und Ethik der Medizin. Philosophische und theologische Anmerkungen. Neukirchen-Vluyn: Neukirchener Verlag.

Saner, H 1995. Geburt und Phantasie. Von der natürlichen Dissidenz des Kindes. Basel: Lenos.

Schapp, W 1981. Philosophie der Geschichten. 2. Aufl. Frankfurt a.M.: Klostermann.

-, 1985. In Geschichten verstrickt. Zum Sein von Mensch und Ding. 3. Aufl. Frankfurt a.M.: Klostermann.

Schneider-Flume, G 2004. Grundkurs Dogmatik. Nachdenken über Gottes Geschichte. Göttingen: Vandenhoeck \& Ruprecht (UTB 2564).

Strawson, P F 1971. Individuals, An essay in descriptive metaphysics. London: Methuen.

-, 1995. Einzelding und logisches Subjekt. Ein Beitrag zur deskriptiven Metaphysik. Stuttgart: Reclam. 
Sturma, D 2001. Person und Philosophie der Person, in: Sturma, D (Hrsg.), Person. Philosophiegeschichte - Theoretische Philosophie - Praktische Philosophie. Paderborn: Mentis, 11-22.

Thönissen, W 2001. Perspektiven und Impulse für eine ökumenische Sozialethik aus christlichem Glauben. ZEE 45, 109-120.

Timm, H 1996. Sprachenfrühling. Perspektiven evangelisch-protestantischer Religionskultur. Stuttgart: Radius.

Trillhaas, W 1970. Ethik, 3. Aufl. Berlin: De Gruyter.

“... und der Fremdling, der in deinen Toren ist" 1997. Gemeinsames Wort der Kirchen zu den Herausforderungen durch Migration und Flucht (Gemeinsame Texte 12). Hannover/Bonn.

Weder, H 1986. Neutestamentliche Hermeneutik. Zürich: TVZ.

Wildfeuer, A 2000. s v Person. Lexikon der Bioethik, Bd. 3. Gütersloh: Gütersloher Verlagshaus, 5-9.

Wilkening F. \& Krist, H 2002. Entwicklung der Wahrnehmung und Psychomotorik. in Oerter, R \& Montada, L (Hrsg), Entwicklungspsychologie. 5. Aufl. Weinheim et al: Beltz PVU, 395-417. 